\title{
An Economically Viable Approach for Induced Breeding of Labeo Rohita by Ovatide, Ovaprim And Carp Pituitary Extract.
}

\author{
Gurpreet Singh Tiwana ${ }^{1}$, Sudhanshu Raman ${ }^{2}$ \\ ${ }^{1,2}$ (Guru Angad Dev Veterinary and Animal Sciences University, India)
}

\begin{abstract}
Indian major carp Labeo rohita was induced breeding in eco-carp hatchery with 3 different inducing agents, viz. ovaprim, ovatide, Carp pituitary extract at fish breeding center at Amloh Distt. Fathegarh Sahib (Punjab) India. Total ten trial doses of ovaprim, ovatide and Carp Pituitary Extract (CPE) used for induced breeding in Labeo rohita. The fertilization was found $61.30 \%$ with ovaprim, $58.50 \%$ with ovatide and $55.96 \%$ with carp pituitary extract treatment. The percentage hatchling was $72.20 \%$ with ovaprim, $66.37 \%$ with ovatide and $59.25 \%$ with carp pituitary extract treatment.A comparison was carried out for fecundity, fertilization, and hatching rate during the induced spawning of Labeo rohita administered single dose of ovaprim and ovatide while carp pituitary extract double dose to female brooder. Ovaprim performed much better than Ovatide and pituitary gland extract.
\end{abstract}

Key Words: Labeo rohita (Rohu); Induced breeding; ovatide; ovaprim; Carp pituitary extract.

\section{Introduction}

Fish culture in freshwater ponds was practised in India as early as 350 B.C., though on a limited scale. Carp culture is common in India. Aquaculture in the State of Punjab is a fast developing income generating activity, providing a quality and low cost protein diet to the people (Agarwal, 1999). At present, nearly 9890 ha is under fish farming as compared to 343 ha in 1980-81 and fish production increased in subsequent years from 2800 to 86000 tonnes, including both capture fisheries and aquaculture, For the last ten years, the States aquaculture production has contributed an annual average growth of 6000 tonnes per annum. The carp culture improves the socio- economic status of fish farmers by adopting new scientific technology for breeding (Nandeesha and Rao, 1989).

The technique of induced breeding was first evolved in Argentina after producing pituitary extract by Houssay 1930 where viviparous fish was injected with the hormone to make premature birth. In the year of 1934, Brazilians were succeeded in induced breeding by pituitary extract. This technique was also followed in America (Merlin \& Hubs) and in Russia (Gerebilisky). In India first attempt of induced breeding was made by Khan in 1937 on Cirrhinus mrigala. Later in 1955 Dr. Hiralal Choudhri applied this tecnque in minor carps (Esomus danricus, Pseudeotropius atherinoides). Ramaswamy and Sunderaraj first induced to breed Clarias batrachus \& Heteropneustes fossilis. The first successful induced breeding on major carps was done by Dr. Hiralal Choudhri 1957 - Cirrhinus mrigala, C. Reba \& Labeo rohita. Parameswaran \& Alikuni successfully bred the exotic Chinese carps - Hypophthalmicthys molitrix \& Ctenopharyngodon idella in 1963.

Many cultural farm fishes like IMC do not breed in captivity. The reason may be environmental and consequently hormonal. Certain environmental parameters like photoperiods, rain, temperature, current of water influence the hormonal activity from pituitary and gonads. Disturbances arise in environment may cause the insufficient release of hormones in captive conditions and thus, the fish does not breed in captivity.

However, the major problem in the carp culture is the non-availability of quality fish seed. In early years fish seeds were collected from river coasts by cloth happas, but this technique was unsafe as with the collection of carp seed, some seeds of predatory fishes were also collected accidentally. Chaudhary and Alihunhi (1957) for the first time successfully carried out the spawning of Indian major carps with induced breeding by pituitary extracts. This technique was then used all over India but the potency and the quality of the pituitaries used for preparing the extract became undependable, and because of this problem there is failure in spawning and results of pituitary extracts in many farms.

Human chorionic gonadotropin (HCG) was then used, as a substitute for pituitary gland but it could not get the success as it was thought (Chonder, 1985). The search for a suitable substitute was going on and then after ovaprim was introduced in the market as a substitute for pituitary gland It is synthetic manufactured by Syndel laboratories inc, Vancouver, British Columbia, Canada. All the fish breeders readily showed acceptance for this drug Nandeeshsa et al., 1990). Ovaprim contains analogue of Salmon GnRH, and dopamine inhibitor required for culturable species. Ovatide is a synthetic compound launched by Hemmopharma, Bombay. It is also a combination of $\mathrm{GnRH}$ analogue with dopamine antagonist pimozide. The preparation of carp pituitary extract the glands are removed carefully from freshly killed the fish called donor fish. For best result the donor fish should be fully ripe and mature. Common carp is the best donor fish, because it breeds through out the year and 
An economically viable approach for induced breeding of Labeo rohita by ovatide, ovaprim and Carp the individuals are available in all parts of the world. The pituitary glands of such species are relatively large. The gland should be collected prior to spawning. However the gland doesn't show species specificity and any carp species can be used as donor. However the glands of relative or closely related species show best result.The present investigation was conducted to ascertain comparative efficacy of ovaprim, ovatide and carp pituitary extract in Labeo rohita.

\section{Materials and Methods}

The experiment was conducted on Mature females and males brooder in carp fish hatchery (Fathegarh Sahib, Punjab) and selected on the basis of their external secondary sexual characters (Jhingran and Pullin, 1985).

Table:1 Dose of ovatide for major carp

\begin{tabular}{|l|c|c|}
\hline & Female (ml/kg body wt.) & Male (ml/kg body wt.) \\
\hline Catla catla & $0.4-0.5$ & $0.2-0.3$ \\
Labeo rohita & $0.2-0.4$ & $0.1-0.2$ \\
Cirrihnus mrigala & $0.2-0.4$ & $0.1-0.2$ \\
Hypophthalmicthys molitrix & $0.4-0.5$ & $0.2-0.25$ \\
Ctenopharyngodon idella & $0.4-0.5$ & $0.2-0.25$ \\
\hline
\end{tabular}

Table:2 Dose of ovaprim for major carp

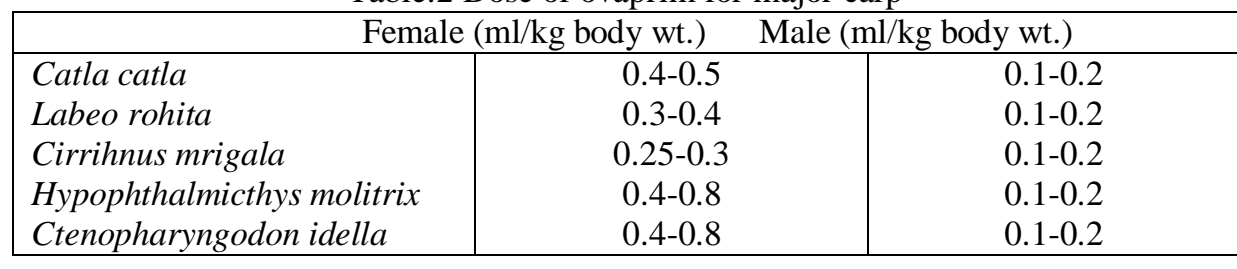

Table:3 Dose of carp pituitary extractfor major carp

\begin{tabular}{|l|c|c|c|}
\hline \multicolumn{3}{|c|}{ Female (mg/kg body wt.) } \\
\hline \multirow{2}{*}{ Catla catla } & Dose I & Dose II & Dose I \\
\cline { 2 - 4 } Labeo rohita & $02-03$ & $06-08$ & $02-03$ \\
Cirrihnus mrigala & $02-03$ & $06-08$ & $02-03$ \\
Hypophthalmicthys molitrix & $02-03$ & $06-08$ & $02-03$ \\
Ctenopharyngodon idella & $04-06$ & $06-10$ & $04-06$ \\
\end{tabular}

\section{Carp Pituitary extract}

The female was given a preliminary dose of $2-3 \mathrm{mg} / \mathrm{kg}$ of body wt( Rohu). The preliminary dose was not given to the male. After an time interval of about $4-6 \mathrm{hrs}$, a second dose of $6-8 \mathrm{mg} / \mathrm{kg}$ of body wt(Rohu).The first dose was given to male of $2-3 \mathrm{mg} / \mathrm{kg}$ of body wt (Rohu) at the time of second dose of female. The dose depends upon the maturity of fish, age, sex and also the environmental conditions.

\section{Injection to breeding stock}

The injection is given intramuscularly (in the muscle) near the tail of the body avoiding the lateral line (lines on both sides of the fish indicating the position of the line of nerves in the fish) and below to the dorsal fin but above from lateral line.) The injection is given intraperitoneal (in the body cavity) at the base of pectoral fin and pelvic fin

Ten females and five male fishes were injected with carp pituitary extract with two dose to female accordingly $2-3 \mathrm{mg} / \mathrm{kg}$ of body wt (Dose I) and $6-8 \mathrm{mg} / \mathrm{kg}$ of body wt at an interval of 5 hours and a single dose to the male $2-3 \mathrm{mg} / \mathrm{kg}$ of body wt at the time of second injection to the females. $0.4 \mathrm{ml} / \mathrm{kg}$ of body wt dose of ovaprim was given to 10 females and $0.2 \mathrm{ml} / \mathrm{kg}$ of body wt dose to 5 males. $0.3 \mathrm{ml} / \mathrm{kg}$ of body wt dose of ovatide was given to 10 females and $0.2 \mathrm{ml} / \mathrm{kg}$ of body wt dose to 5 males Only a single dose of ovaprim and ovatide was given to both the sexes.

\section{Results and Discussion}

The results of the trials are summarized as Fecundity, Fertilization and Hatching rates.

\section{Fecundity}

During the experiment it was observed that fecundity (Egg production) rate was better under the Ovaprim treatment as compared to the Ovatide and carp pituitary extract. Ovaprim perform 0.38-lac eggs $/ \mathrm{kg}$, carp Pituitary extract $0.35 \mathrm{lac}$ eggs $/ \mathrm{kg}$ and ovatide as $0.37-\mathrm{lac}$ egg $/ \mathrm{kg}$ on average basis. Fecundity remains high for Ovaprim treated fish as compared to ovatide and carp pituitary extract treated fish.

Comparison of Ovatide, Ovaprim and carp pituitary extract for different parameters in female, Labeo rohita. 
An economically viable approach for induced breeding of Labeo rohita by ovatide, ovaprim and Carp

\begin{tabular}{|c|c|c|c|}
\hline Parameter & Ovatide & Ovaprim & Carp Pituitary extract \\
\hline No. of females treated & 10 & 10 & 10 \\
\hline Total weight of females & $15.3 \mathrm{~kg}$ & $15.0 \mathrm{~kg}$ & $15.0 \mathrm{~kg}$ \\
\hline Total no. of eggs & 379400 & 385620 & 351200 \\
\hline Total no. of fertilized eggs & 221950 & 236400 & 196540 \\
\hline Total no. of hatchling & 147323 & 170681 & 116452 \\
\hline Overall fertilization percentage & $58.50 \%$ & $61.30 \%$ & $55.96 \%$ \\
\hline Overall hatching percentage & $66.37 \%$ & $72.20 \%$ & $59.25 \%$ \\
\hline Average no. of eggs/Kg & 24797 & 25708 & 23413 \\
\hline Average no. of fertilized eggs $/ \mathrm{kg}$ & 14506 & 15760 & 13102 \\
\hline Average no. of hatching/kg & 9628 & 11379 & 7763 \\
\hline
\end{tabular}

\section{Fertilization rate}

Fertilization rate with Ovaprim was calculated as $61.30 \%$ while for Ovatide it remained as $58.50 \%$ and $55.96 \%$ for carp pituitary extract. So Ovaprim has $2.8 \%$ and $5.34 \%$ better results over ovatide and carp pituitary extract for fertilization rate of eggs.

\section{Hatching rate}

As the hatching percentage of eggs is concerned for the Ovaprim, it remained as $72.20 \%$ while for ovatide as $66.37 \%$ and for carp pituitary extract $59.25 \%$ which revealed that Ovaprim gave $5.83 \%$ and 12.95 better performance over ovatide and carp pituitary extract for hatching rate.

Experiments were conducted in July with temperature around $28^{\circ} \mathrm{C}$, little showers of rain and weather being conducive for breeding. fishes injected with carp pituitary extract spawned after $16 \mathrm{hr}$, while females injected with ovaprim and ovatide spawned within $9 \mathrm{hr}$. The positive response of Labeo rohita to ovaprim indicated the higher potency of this drug in inducing the spawning. Certain drugs have been tested for induced spawning in fishes with variation in the percentage of success (Harvey and Hoar, 1979). However, the difference in dosage among different species is due to the varied levels of dopamine activity (Billard et al., 1983; Peter et al., 1986).

In this study only a single dose of ovaprim and ovatide induced spawning within $9 \mathrm{hr}$ while the carp pituitary extract were given two doses to female, still their spawning was delayed and the fertility by ovatide and carp pituitary extract was found less than those of the ovaprim injected. Peter (1986) had ascribed as self potentiating action of the releasing hormone to some drugs when given in two doses.

In India, most of the breeders have been preferring ovaprim, as a survey showed that only 10 to $15 \%$ of fish breeders use carp pituitary extract due to its complexity of technique (Dehadrai, 1986). Ovaprim is effective in induced spawning because it contains Salmon GnRH, native peptide found in most teleosts, also contains a dopamine inhibitor (brain neurotransmitter). Our results indicate that ovaprim might be considered best substitute over ovatide and carp pituitary extract during induced breeding.

\section{Acknowledgements}

The authors would like to thank the College of Fisheries, Punjab, India for technical support, provision of fish and accessing their facilities for experiments.

\section{References}

[1] Agarwal, S.C. 1999. Aquaculture in Punjab. National workshop on sustainable aquaculture in Punjab, 21-22 Jan 1999, PAU, Ludhiana.

[2] Billard, R., K. Alagarawami, R. E. Peter and B. Breton. 1983. Potentialisation per le pimozide des effects du LH-RH-A sur la secretion gonadotrope hypophyaire l'ovulation et la spermiation chez la carpe commune (Cyprinus carpio). C. R. Acad. Sci. Paris 296:181-184

[3] Chaudhari, H. and K.H. Alikunhi: Observations on the spawning in Indian carps by hormone injection. Curr. Sci., 26,381-382 (1957).

[4] Chondar, S. L.: HCG a better substitute for pituitary gland for induced breeding of silver carp on commercial scale. In: Proceedings of the second International conference on warm water aquaculture. finfish, Hawaii, G.S.A., pp. 521-534 (1985).

[5] Dehadrai, P. V. 1986: Carp seed production in India, p. 33

[6] Harvey, B. J. and W. S. Hoar. 1979. The theory and practice of induced breeding in fish. IDRC-TX 21e. 48p.

[7] Jhingran, V.G. and R. S. V. Pullin: A hatchery manual for the common chinese and Indian major carps. Asian development bank and International centre for living aquatic resources management, Manila, Philippines. pp. 191 (1985).

[8] Nandeesha, M.C. and K.G. Rao: Recent developments in carp culture technology in India with special reference to the state of Andhra Pradesh. In: Proceedings of the workshop on fish culture management techniques and nutrition, (Eds: Huisman et al.) 1419 November, Malang pp. 203-210 (1989).

[9] Nandeesha, M.C., K.G. Rao, R. Jayanna, N.C. Parker, T.J. Varghese, P. Keshavanath and H.P.C. Shetty: Induced spawning of Indian major carps through single application of Ovaprim In: The second asian fisheries forum, (Eds: R. Hirano and M. Hanyu). Asian Fisheries Society, Manila, Philippines. pp. 581-585 (1990)

[10] Peter, R. E., J. P. Chang, C. S. Nahorniak, R. J. Omeljaniuk, M. Sokolowska, S. R. Shih and R. Billard. 1986. Interaction of catecholamines and sGnRH in regulation of gonadotropin secretion in teleost fish. Recent Prog. Horm. Res. 42:513-548.

[11] Ramaswami . S. and Sundararaj B. I. (1956): Induced spawning In the Indian Catfish Science. 1231080. 